Review Article

\title{
Advances in the use of GABAergic interneurons for the treatment of epilepsy
}

\section{Federica Frisina ${ }^{1,2 \#}$, Giulia Valetti ${ }^{1,2 \#}$, Giulia Zuccarini ${ }^{1,2 \#, ~ L u c i a n o ~}$ Conti $^{3 *}$ and Giorgio R Merlo ${ }^{1 *}$}

'Department of Molecular Biotechnologies and Health Sciences, University of Torino, Italy

${ }^{2}$ Maria Pia Hospital, Torino, Italy

${ }^{3}$ Department of Cellular, Computational and Integrative Biology - CIBIO, University of Trento, Italy

\section{Abstract}

Forebrain GABAergic neurons, the main inhibitory type of neuron in the cortex and hippocampus, represent a highly heterogeneous cell population that has been implicated in the predisposition to epilepsy and the onset of seizure. Earlier attempts to restore inhibition and reduce seizure in animal models of epilepsy have been carried out using embryonic basal forebrain tissue as source of immature GABAergic progenitors in cell-based therapies, with promising results. For therapeutic strategies this approach appears unrealistic, while the use of pluripotent stem cells to obtain immature GABAergic neurons opens new and promising avenues. Research on neural stem cells and pluripotent stem cells has greatly advanced and protocols have been established to efficiently direct progenitor cells to differentiate towards the GABAergic lineage. However, being highly heterogeneous, these neurons are difficult to be fully represented in vitro. Better knowledge on the expressed gene profiles, at single cell level, and the differentiation trajectory of these neurons will consent a more precise monitoring of the differentiation steps. Here we review the current literature about how to obtain and characterize genuine inhibitory neurons, how these can be grafted in animal models (and one day possibly in human) and which diseases could potentially be targeted and the efficiency of therapeutic outcome. The main obstacles that need to be overcome are: a) choice of an appropriate animal model, b) availability of human cells prone to GABA differentiation, c) the full representation of all IN subtypes, their proportions and their physiological activities, d) how to monitor them on the long-term after transplant.

\section{Introduction}

Epilepsy is a severe neurological disease affecting more than 70 million people worldwide. It is characterized by unpredictable and abnormal electrical discharges resulting in recurrent seizures [1]. Epilepsy has been causally linked to altered excitatory/inhibitory neuronal balance. Based on this theory, GABAergic interneurons (INs) are regarded as the primary inhibitory neurons whose activity failure results in hyperactivity of the epileptic circuitry [2].

Anti-epileptic drugs (AEDs) are the forefront treatment for seizure control [3]. About one third of patients with epilepsy, however, suffer from intractable seizures that are unresponsive to AEDs [4]. Furthermore, patients that respond to AEDs typically face serious adverse side effects [5]. Surgical removal of affected brain tissues or implanting neurostimulator devices are effective options only for a

\section{More Information}

*Address for Correspondence: Giorgio R Merlo, Department of Molecular Biotechnologies and Health Sciences, University of Torino, Via Nizza 5210126 Torino, Italy, Tel: +39 0116706449; Fax: +39 0116706432; Email: giorgioroberto.merlo@unito.it

\#Reported in alphabetic order, contributed equally to the work are should be considered first author

Submitted: 24 August 2019
Approved: 03 September 2019
Published: 04 September 2019

How to cite this article: Frisina F, Valetti G, Zuccarini G, Conti L, Merlo GR. Advances in the use of GABAergic interneurons for the treatment of epilepsy. J Stem Cell Ther Transplant. 2019; 3: 009-022.

\section{DOI: 10.29328/journal.jsctt.1001014}

Copyright: (c) 2019 Frisina F, et al. This is an open access article distributed under the Creative Commons Attribution License, which permits unrestricted use, distribution, and reproduction in any medium, provided the original work is properly cited

Keywords: Neural stem cells; Neuronal differentiation; Inhibitory neurons; Epilepsy; Cell therapy

Abbreviations: 5 HT3aR: serotonin Receptor 3a; AED: Anti-Epileptic Drug; CB: Calbindin; CGE: Caudal Ganglionic Eminence; CNS: Central Nervous System; CR: Calretinin; DCX: Doublecortin; ESC: Embryonic Stem Cells; fEPSP: field Excitatory Postsynaptic Potential; GABA: Gamma-AminoButirric Acid; GFAP: Glial Fibrillary Acidic Protein; HFO: High Frequency Oscillation; IN: Inhibitory Neurons or InterNeuron; iPSC: induced Pluripotent Stem Cells; KA: Kainic Acid; LGE: Lateral Ganglionic Eminence; MES: Maximal Electroshock; MGE: Median Ganglionic Eminence; NeuN: Neuronal Nuclear Antigen; nNOS: Neuronal Nitric Oxide Synthase NPY: Neuropeptide Y; NSC: Neural Stem Cells; PTZ: Pentylenetetrazole; PV: Parvalbumin; SE: Status Epilepticus; SRS: Spontaneous Recurrent Seizures; SST: Somatostatin; TLE: Temporal Lobe Epilepsy; VIP: Vasoactive Intestinal Peptide

\section{Check for updates}

fraction of drug-refractory patients [6]. Furthermore, current treatments of epilepsy often enhance some of the deficits in cognitive functions typically associated with epilepsy, leading to poor compliance [7]. Thus there is urgent need to find alternative strategies, especially for AED-refractory patients.

Basic research on stem cells, their cellular and molecular properties, and their potential use in cell-based therapeutic approaches has greatly advanced, in recent years. Intense efforts have been placed on the establishment of protocols to efficiently direct differentiation of stem and progenitor cells towards several lineages. Among these GABAergic INs, the 
main inhibitory neuronal type in the mammalian forebrain, have been obtained with good enrichment both from mouse and human stem cells, and hold promises for their potential use in clinic [8]. However, several problems and drawbacks arise, among which the highly heterogeneous neurochemical and networking properties of INs, the difficulty to fully recapitulate their developmental trajectories, and their fate upon transplant in the long term.

In spite of difficulties, attempts to use inhibitory GABAergic INs in cell-based therapies are showing some efficacy to attenuate the epileptic phenotype in selected animal models. Here we review the most relevant literature focussing on how to obtain and characterize genuine inhibitory INs and how these can be grafted in animal models (and one day possibly in human) of epileptic conditions, showing promising results that should foster future research in this area.

\section{Types, origin and functions of forebrain INs}

The mammalian cerebral cortex is typically a six-layered organization which includes two major classes of neurons: the excitatory pyramidal cells that project to cortical and subcortical targets, and the inhibitory non-pyramidal cells, the cortical INs. The hippocampus, that has a similar embryonic derivation, is equally composed of pyramidal projection and inhibitory neurons, although with a different layering organization and composition [9].

While pyramidal cells project their axons to distant region within or outside the cortex, and predominantly transmit signal using glutamate as neurotransmitter, INs have short, locally extending axons which connect to nearby neurons and use primarily $\gamma$-aminobutyric acid (GABA) as neurotransmitter. Within the mammalian cortex GABAergic INs represent 10$20 \%$ of the total cortical neuronal population, depending on the region examined, and are the only source of GABA [9].

Adult INs are highly heterogeneous from several points of view, and consequently several subclasses have been identified whose classification relies on morphologic, histologic, molecular and neurochemical features or electrophysiological properties, or combination of these criteria $[10,11]$. In the rodent cerebral cortex and hippocampus, more than twenty GABAergic IN subtypes have been documented. The expression of three calcium-binding proteins calretinin (CR), calbindin (CB), parvalbumin (PV), or other markers such as somatostatin (SST), neuropeptide Y (NPY), cholecystokinin (CCK), serotonin receptor 3a (5HT3aR), vasoactive intestinal peptide (VIP), reelin, and neuronal nitric oxide synthase (NOS), coupled to their distinctive morphology, connectivity, synaptic properties, and intrinsic firing properties are features that help to differentiate the various IN subtypes [12,13]. Recent in depth molecular analyses using single-cell RNAseq confirm and extends the extraordinary variety of INs $[11,14,15]$ further indicating that such diversity might be specified as early as the progenitor state [16].
The origin and development of forebrain INs has been thoroughly studied in the rodent brain: they derive from progenitors that reside in basal regions of the embryonic brain, namely the median ganglionic eminence (MGE) (for cortex and hyppocampus), the lateral ganglionic eminence (LGE) (for olfactory bulb INs) and the caudal ganglionic eminence (CGE) [17-21]. Cortical and hippocampal INs derive mainly from the MGE and the CGE, and the majority of them express SST or PV, and originate from $\mathrm{Nkx} 2.1^{+}$progenitors in the MGE and the preoptic area [22-25].

Following exit from the cell cycle, the immature INs migrate into the cortical plate following stereotyped trajectories and timing, reaching the cortex and hippocampus primordial where they mature and integrate into local circuits $[12,26]$. INs migration follows several tangential routes and is critical for the correct establishment and integration of INs during embryonic and early postnatal life in both humans and rodents [21,27]. In human, in addition to interneuron genesis occurring within the GEs [28], IN progenitors have been detected in cortical progenitor zones, particularly at the anterior brain regions [29,30]. Intracortical interneuron genesis may start earlier than the time when tangential migration of INs from the MGE occurs [29].

As a general feature, GABAergic INs play a fundamental role in controlling the neural circuitry and network activity of the central nervous system (CNS), forming numerous connections with local pyramidal neurons or other INs and participating in the construction of functional networks. Cortical INs exert an essential inhibitory function within local cortical circuitry, modulate and coordinate signal transmission from pyramidal cells, synchronize oscillatory activities and participate in computational functions [31,32].

Each distinct IN subtype shows peculiar morphological and electrophysiological properties [32-34] and thus it is generally believed that each subtype of IN carries out specialized tasks in the control of information flow within the cortex. However, the specific function of each IN subtype, especially in the context of the global functioning of neuronal networks and their role in epileptic seizure, is still incompletely defined.

\section{The involvement of INs and reduced GABAergic inhibition} in epilepsy

Epilepsy reflects abnormal and massive hypersynchronous discharges from large assembly of neurons in cortical networks $[35,36]$. Temporal lobe epilepsy (TLE) is the most common form of epilepsy, characterized by the presence of epileptic foci in the limbic system, initial precipitating injury event (which induces the initial brain damage), the presence of a latent period and hippocampal sclerosis which leads to a reorganization of the neuronal network [37]. The etiology of epilepsy is complex and heterogenous, comprising structural, genetic, infectious, metabolic, immune and/or other unknown causes [38]. 
Epileptic seizure might be caused by a variety of factors [39-42]. Altered excitation-inhibition balance is a proposed common pathophysiological feature of multiple seizure and neuropsychiatric disorders, including epilepsy, schizophrenia and autism [43-51]. Altered IN genesis, migration and function may logically contribute to modify the excitatory-inhibitory balance, and specifically a reduced inhibition is the expected consequence of reduced number or hypoactive INs within cortical and hippocampal circuits. Failure or interference of IN migration leads to abnormal distribution of INs and alterations of the inhibitory control of the postnatal brain but also deprivation of the neurotrophic role of GABA in early development, resulting in epilepsies or other neurological disorders [26,52-56].

One specific subtype of INs has been critically involved in epilepsy, i.e. the fast-spiking PV-expressing INs [57-59]. However, the involvement of other subtypes might be under evaluated, since they are less studied. Indeed, the role of INs and altered excitation/inhibition balance in epilepsy is far from being completely understood. Recent evidence argues for the context-dependent, possibly excitatory roles that GABAergic cells play in epileptic circuitry. The dynamic, context-dependent role of GABAergic INs in seizure requires further investigation of their functions at single cell and circuitry level [60].

The causes of INs dysfuctions associated with epilepsy range from genetic mutations, altered migration, altered lamination and fine histoanatomical organization, connectivity and plasticity defects. Indirectly, also metabolic and hormonal condition may influence the function of IN, and last but not least the exposure of the developing brain to stress or substances with teratological activity [61].

Dysfunction of cortical INs has been implicated in a wide range of neurological and cognitive/behavioral disease [33,62-64], leading to the term "interneuronopathy", now widely used. The variety of neurological and cognitive disturbances linked to altered IN development and functions is not surprising, considering also the infantile transitional stage in the maturation of the GABAergic system, including the migration of INs in the cortical cortex, development of GABAergic synapses and dendritic arbor, as well as the changing expression, composition, and function of GABA-A receptors, resulting from the depolarizing to hyperpolarizing switch in their responses.

A broad set of evidence implicate INs disfunctions in epilepsy $[65,66]$; and these include:

1. Human neurodevelopmental conditions comprising epilepsy, associated with mutations in IN-relevant genes; such is the case of the West and the Dravet syndromes. Mutations in over 25 epilepsy-associated genes in human have been proposed to promote over-excitability, some of them acting by reducing inhibition [66]. In tissue from patients with TLE, hippocampal seizure foci were characterized by the loss of SST-expressing INs $[67,68]$.

2. The association between a spectrum of early-onset epilepsies and neurodevelopmental or other neurological disorders that manifest as interneuronopathies in animal models. Such is the case of mice with mutations in $\operatorname{Arx}$, in Scn1A and in Apc. Linked to this, the reduced IN population in rodent models of genetic (Arx mutant) and induced infantile spasms [65]. On the same line of evidence, the genetic mutation of Snc1a disrupts IN function and physiology and recapitulates the Dravet syndrome, characterized by infantileonset drug-resistent epilepsy. In mice, the impairment of the activity of $\mathrm{PV}^{+}$and $\mathrm{SST}^{+}$INs leads to a disinhibition of the cortical network and a Dravet-like phenotype [69]. In a nonhuman primate model of neocortical focal epilepsy, a strong decrease in the number of GABAergic synapses was observed at epileptic foci [70].

3. The association between altered high-frequency oscillations (HFO) (such as $\gamma$ and $\theta$ oscillations) and epilepsy $[71,72]$. HFO are typically recorded from brain regions capable of generating TLE, and altered HFO have been recorded in models of other epileptic disorders, such as neocortical epilepsy, genetically-caused epilepsy and infantile spasms [72]. Recent improvements in recording technologies and the introduction of optogenetics into epilepsy research has led to a better elucidation of the cellular substrates of epileptic HFO and of the role of altered neuronal networking. Although the role of INs in the generation of HFO is not fully defined, there are indications that a specific subpopulation of INs, the fastspiking $\mathrm{PV}^{+} \mathrm{INs}$, are central to the emergence and control of $\gamma$ oscillation. Altered $\mathrm{PV}^{+}$neuron number and function have increasingly been associated to increase risk of epilepsy [73]. Likewise, INs have been implicated in the control of $\theta$ frequency oscillations [71].

4. Recent optogenetic studies have shown that enhancing the inhibitory function of GABAergic INs efficiently leads to suppression of seizures, in accordance with the concept that the excitatory-inhibitory balance shifts towards the excitatory regime in epilepsy $[60,74,75]$.

5. Treatment with AEDs acting on the GABAergic synapse represents the most widely used clinical approach to treat epilepsy, and clinical data show that in these alleviate the manifestation during seizures, at least in the major of cases [76]. Treaments with AEDs however do not cure epilepsy, while on the other side systemic treatments with AED to prevent episodes may lead toserious side effects. More effective and local treatments are needed, that attempt to restore normal connectivity and excitation-inhibition balance.

\section{Deriving GABAergic neurons from progenitor cells in vitro}

As a most straight-forward approach, MGE embryonic cells can be dissociated directly from explants of the MGE 
tissue and maintained in vitro in adherent conditions. These cells can be plated in culture and can undergo maturation into INs expressing bona fide mature markers [77]. This approach has been widely exploited with mouse tissues for many experimental works in which single cells can be labeled with fluorescent tracers and monitored for migration, neuritogenesis and synaptogenesis. However, this method is poorly applicable to human settings since the approach is limited by the scarceness of tissue (i.e. fetal MGE from aborted human embryos).

To overcome this barrier, in the last decade several protocols to obtain bona-fide MGE cells from pluripotent stem cells (PSC) have been described [8]. Mouse and human PSCs have been shown to have a broad potential to generate multiple CNS neuronal subtypes [78]. The possibility to derive mature forebrain INs directly from PSC holds great promises for research and therapeutic applications. Since both embryonic stem cells (ESCs) and iPSC (induced PSC) have been successfully derived from rodents and human, these represent the ideal source of cell-based therapies therapies, raising hopes for their applications in the field of neurodevelopmental or neurodegenerative disorders.

Initial studies have been performed with ESCs or iPSC of mouse origin and then extended to the human counterpart. In general, these protocols are based on the exposure of PSCderived neuroectoderm tissue to specific morphogens/signals known to instruct embryonic MGE cells specification during development $[79,80]$. Watanabe and colleagues described that stage-specific Wnt pathway inhibition in mouse ESCs can induce the generation of rostral Foxg $1^{+}$(i.e. telencephalic) progenitors and that their subsequent exposure to sonic hedgehog $(\mathrm{SHH})$ drives the regionalization to a ventral $\mathrm{Nkx} 2.1^{+}$ forebrain MGE progenitor identity [81]. Although this study represented a milestone in the field, the efficiency was quite low and the cultures contained also Pax $6^{+}$telencephalic dorsal progenitors (i.e. progenitors of cortical excitatory neurons).

Attempts to generate more pure cultures have been performed by exploiting reporter-based selection approaches. This strategy allows to better define factors for effective and more selective MGE regionalization and demonstrates that while FGF8 exposure can promote MGE identity, FGF15/19 had a negative effect, being effective in promoting CGE cell fates [82]. The most significative example of reporter-based selection approaches has been the use of Lhx6::GFP-expressing mouse ESCs, which allowed to select enriched populations of MGE progenitors in vitro [83]. This strategy showed to be successful (although with low efficiency) in generating $\mathrm{SST}^{+}$ and $\mathrm{PV}^{+} \mathrm{GABAergic}$ INs in vivo and also showed their in vivo relevance after intracerebral transplantation [83].

It was then shown that forced expression of $\mathrm{Nkx} 2.1$ resulted in higher and prolonged expression of Lhx6 and improved efficiency of cortical IN generation, in the absence of SHH [45]. Likewise inducing the expression of Nkx2.1, Dlx2 and Lmo3 resulted in an ever-higher efficiency of MGE-type IN generation, with a preference of $\mathrm{PV}^{+}$over $\mathrm{SST}^{+}$ young neurons [84]. Transplantation studies using these neurons substantially confirmed these findings [85]. Thus recapitulating the physiology of development in vitro results in the generation of apparently genuine INs.

Still, the differentiation of progenitors towards INs entails formidable problems, due to extreme diversification of IN subtypes and their early cell fate determination. One of the key issues is the lack of adequate molecular and functional markers to fully define them, and the poor knowledge on the temporal dynamic of their expression. Until few years ago INs were characterized at a population level by using few neurochemical markers, with the caveat that these analyses represents averages of cell behavior and cell states. While individual differences cannot be appreciated. Today we begin to appreciate the full complexity and variability of the molecular states of these neurons at the single-cell level $[15,16]$; in this respect Close and colleagues examined stepwise changes in gene expression profiles of in vitro differentiating progenitors, using a single cell approach, and then compare these with fetal cortical INsat various ages [86]. Their analysis yielded results that substantially confirm all key finding in vivo, while at the same time pointing to novel disease-relevant differentiation determinants, to be included in future monitoring efforts.

Differently form mouse PSCs, the generation of cortical INlike cells from human ESCs and iPSCs lagged behind mainly because of the much longer time required for differentiation of human cells, their tendency to die after replating, and the lack of methods to purify IN progenitors or post-mitotic precursors from the mixed population that occur with every protocols. While some study demonstrated to capacity of human iPSCs to generate telencephalic-like progenitors [87], two studies were critical in moving the field forward. First, the optimization of aprotocol based on the strong dual inhibition of the TGF $\beta$ pathway with the peptide noggin and the small molecule SB431542 during initial phases of differentiation, showed that neural ectoderm can be efficiently obtained from pluripotent stem cells [88]. Second, also in human, differential WNT signal agonism or antagonism can be used to drive telencephalic (Foxg $1^{+}$) human ES-derived cultures into cortical-like $\left(\mathrm{Pax6}^{+}\right)$or MGE-like $\left(\mathrm{Nkx} 2.1^{+}\right.$) progenitors [89].

Now, a relatively rapid and uniform generation of telencephalic progenitors has been achieved. These progenitors can be "dorsalized" or "ventralized" into a variety of subfields and differentiated into a variety of neuron types, including cortical INs [90-92]. While these studies are promising, caution needs to be applied as they show two major challenges towards safe and reliable generation of human INs. First is the protracted maturation stage of the human MGE progenitors to give rise to functional INs. Second, 
only few cells actually acquire a PV+ identity, which in turn could be the consequence of the longer differentiation time of these particular neurons. As much attention is drawn towards this disease-relevant neuron type, our knowledge is possibly biased towards these neurons.

Despite the challenge in generating reliable and stable human INs, two studies showed some degree of efficacy in the treatment of seizure in mouse models, in vivo [93,94]. Based on this, research in the field is rapidly proceeding trying to answer these crucial questions: a) can we obtain the desired IN type and subtype? b) can we retain their ability to establish inhibitory synapses on the correct neuronal targets? c) can we avoid long and complex protocols, inevitably leading to considerable cell loss and increased variability? Considering the high molecular variability, a valid monitoring method will be single cell RNAseq analyses [86].

Alternative strategies to the direct generation of INs from PSCs have been also developed.

Among them there is the possibility to derive stable and homogeneous lines of adherent neural stem cells from iPSCs and maintain them in monolayer culture while preserving a full and homogeneous commitment towards the GABAergic lineage $[95,96]$. These adherent monolayer cultures show limited capacity to maintain a defined dorso-ventral identity $[97,98]$ and to generate multiple brain cell types, other than GABAergic neurons $[99,100]$. This approach has been shown to work also for human cells [101-103].

Finally, direct conversion strategies that allow to directly convert somatic cells (i.e. fibroblasts) into forebrain INs by forced expression of specific transcription factors have been recently described [104,105]. This technique can produce functional forebrain INs without the requirement to pass through a pluripotent state but the overall efficiency, in particular for the human system, is quite limited.

\section{The choice of cells used in models of epilepsy}

Cells from various sources and maintained in different conditions have been tested in preclinical models of epilepsy following grafting into distinct regions of the brain (Figure 1). The donor cells examined include hippocampal precursor cells, neural stem cells (NSCs), primary GABAergic neurons or GABAergic precursor cells derived from either embryonic LGE or MGE, or from mouse and human ESCs and iPSCs [106]. All these cells have been shown to modulate hippocampal plasticity, modify epileptogenesis, reduce the frequency of spontaneous recurrent seizures and alleviate related comorbidities, although with varying efficiency. The outcomes varied depending on the animal model employed, the timing of grafting intervention after the first seizures and the timepoint of measurement of SRS [106].

1. NSCs short-term expanded from the embryonic MGE or from the postnatal subventricular zone (SVZ) are good
A

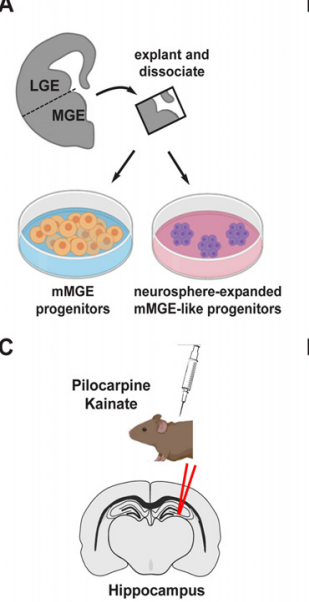

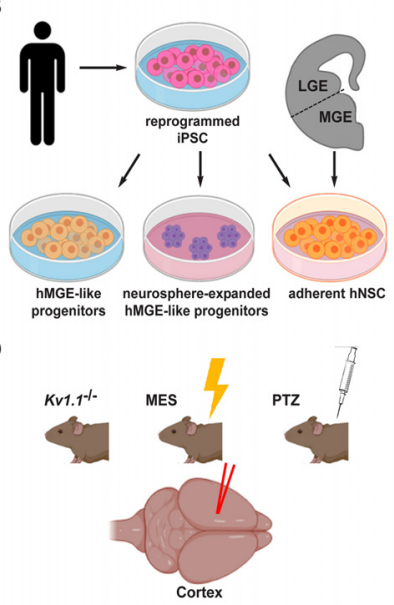

Figure 1: Schematic representation of the main cell-based experimental strategies to epilepsy.

A,B. The source of IN progenitor cells of rodent (A) or human (B) origin, used in experimental therapies. In rodents, most studies use progenitors obtained from dissociated MGE, or neurosphere derived from the same progenitors. In human, research is focusing on the use of iPSC derived from somatic cells as a source of IN progenitors to be used in cell-based therapies.

C,D. The most widely used models of epilepsy (induced or spontaneous) and the corresponding experimental strategies adopted for cell-based treatments in the hippocampus (C) or in the cortex (D). Spontaneous epilepsy is the consequence of genetic manipulation disrupting disease-relevant genes. On the other side, seizure can be induced physically by MES, and chemically with PTZ, pilocarpine or kainate. Abbreviations are indicated in the text.

candidates as donors, being multipotent and self-renewing [107]. To be noted, NSC grafting implies the possibility to replenish both new GABAergic INs and new astrocytes into a brain area, the later secreting a multitude of neurotrophic factors and anticonvulsant proteins such as GDNF [108,109]. Due to their ability to engraft into the dentate gyrus and influence hippocampal neurogenesis [107], NSCs might also be able to ameliorate those cognitive functions which typically decline in chronic TLE.

2. Cells dissociated from embryonic MGE can be maintained in culture and generate INs able to migrate in the host brain when transplanted in early postnatal mice, expressing INs markers PV, SST, NPY and CR [22,110]. These cells are characterized by the expression of markers such as NeuN, doublecortin (DCX) and Hu24, but they are negative for nonneuronal markers such as glial fibrillar acidic protein (GFAP), vimentin and Olig2 [111]. Most importantly, MGE-derived neurons establish synapses and direct evidences suggest that these cells can functionally integrate and influence GABAmediated inhibition in the host brain [110]. Moreover, in vitro electrophysiology studies confirm that these cells have firing properties typical of mature INs [111].

3. Obtaining genuine INs from hiPSC to be used in cell-based therapy circumvents two key issues: the limited availability of fetal brain material and the use of autologous, patient-specific cell [112]. hiPSC-derived MGE-like progenitors potentially yield both cortical-like and striatal-like GABAergic INs that express SST, CR, and CB. Electrophysiological analyses have 
shown a slow maturation of these INs. Following injection into the mouse brain, hiPSC-derived IN precursors dispersed from the injection site, matured into subtypes, and functionally integrated into the host cortex. They did not migrate as extensively as dissociated embyonic MGE cells and some cells remained at the injection site. This suggests that optimization of the iPS differentiation and/or development of methods to purify migratory MGE-like cells may be needed [92].

\section{Advances in the use of GABA-committed progenitors in models of epilepsy}

There is urgent need to develop new therapies that directly target epileptic foci restoring proper inhibition and synchronicity, rather than more systemic interventions $[93,113]$. One strategy that has been proposed in recent years is to restore normal circuit function by transplanting cells capable to differentiate into GABAergic neuronsat the seizure focus. This approach has been recently tested experimentally and validated, owing to improved tools and methods for cell propagation and differentiation in vitro $[106,114]$ (Figure 1).

In this section we will illustrate the most recent developments and discuss critical issues in moving these experimental therapies into clinic. We will also highlight aspects such as cell-survival, migration, differentiation into INs subclasses and functional integration in the host network, and especially emphasizing the long-term effects of different grafting approaches. For clarity, we have subdivided the results of grafting into the hippocampus from those obtained in the cortex, justified by the fact that TLE, the most common type of epilepsy in adults, initiates at the hippocampus. Key observations are summarized in table 1 (hippocampus) and table 2 (cortex).

Hippocampus: TLE in rodents can be pharmacologically induced by systemic injection of pilocarpine or kainic acid (KA). These treatments recapitulate the status epilepticus (SE), followed by a latent period and the subsequent appearance of spontaneous recurrent seizures (SRSs) representing the chronic phase. These treatment also induce functional and histoanatomical changes in the hippocampus, such as degeneration of dentate hilar neurons and some pyramidal neurons in CA1 and CA3 regions, differentiation of dentate granule cells, reduction in the number of GABAergic INs, aberrant sprouting of dentate mossy fibers, hippocampal hyperexcitability and learning and memory deficits $[37,93,107,115,116]$.

A first attempt exploited an established cell line of uncommitted human pan-neuronal stem cells (hNSCs) obtained from dissociated fetal brain tissue. These cells were grafted in the hippocampus of rats 24 hrs after the cessation of pilocarpine-induced SE [31], and the anti-epileptic effects were evaluated 28-35 days after. The grafts resulted in a significant reduction of seizure frequency, duration and severity, associated with reduced aggressiveness. Six weeks after grafting, hNSCs had migrated in various hippocampal areas, in the amygdala and piriform cortex; 42 days later the number of grafted cells in CA1, CA3 and hilus was diminished, while it remained unchanged in CA2 and granule cell layers. GABAergic INs, representing $26 \%$ of grafted cells, were found in the hippocampus and piriform cortex, and $30 \%$ of these expressed PV. A small percentage of glutamatergic $\left(\mathrm{GluR2}^{+}\right)$and astrocytes $\left(\mathrm{GFAP}^{+}\right)$was also found in the CA1 area. The grafted cells did not acquire granular or pyramidal phenotypes, suggesting that hNSCs mostly differentiated into GABAergic INs. This was further confirmed by recording field excitatory postsynaptic potential (fESPS) in CA1 and stimulation of Schaffer collateral fibers. These experiments showed that the fEPSP amplitudes of hNSCs-transplanted group was significantly smaller compared to controls. Thus, the attenuation of seizure was associated with an enhancement of inhibition due to increased GABAergic activity in the damaged hippocampus [31]. In this study, the long-term fate of the transplanted cells, in terms of survival, senescence and stability of the differentiated phenotype, was not assessed.

In a subsequent study, GABAergic progenitors obtained from dissociated mouse embryonic LGE were used [117]. The cells were pre-treated with FGF2 and caspase inhibitor bilaterally grafted into the hippocampi on KA-treated rats. Grafing was done four days after the appearance of SE. The majority of surviving grafted cells (33\% of the total) differented into NeuN+ cells, a large percentage of which was GABAergic, further subdivided in $\mathrm{CB}^{+}, \mathrm{PV}^{+}, \mathrm{CR}^{+}$and $\mathrm{NPY}^{+}$neurons (Table 1). This study performed a long-term follow-up, i.e. 9-12 months after grafting, and showed a much reduced frequency (between -67 and $-89 \%$ compared to controls) of SRSs but observed no rescue of the aberrant mossy fiber sprouting [117]. Interestingly, although the LGE is not the physiological source of cortical and hippocampal INs, these results suggest that LGE and MGE progenitors are interchangeable when used as a source of cells for grafting, reasonably because their behavior might be strongly context-dependent.

MGE-progenitor cells dissociated from mouse embryonic brains were also used for transplantation studies into the hippocampi of adult mice, 9-20 days after pilocarpine-induced SE [115]. Starting from 7days after transplantation the grafted cells exhibited a bipolar migratory morphology and showed a survival rate of $>30 \%$. Sixty days after grafting, cells were found to participate in host inhibitory local circuits, with a survival rate of about $15 \%$ and showing features of mature INs. Within 2 months, the grafted cells differentiated into GAD67 ${ }^{+}$ INs, expressing a wide set of neurochemical markers including SST, nNOS and PV (Table 1). Very few cells expressed glial lineage markers. The authors characterized the grafted cells for their electrophysiological properties and RNA expression profiles. The profiling results $26 \%$ fast spiking, $41 \%$ regular nonpyramidal spiking, $9 \%$ late spiking and $24 \%$ burst spiking; all expressing gene markers typical of the MGE lineage of INs such as Lhx6) were consistent with an MGE-derived mature IN 
Table 1: Grafting approaches in the hippocampus.

\begin{tabular}{|c|c|c|c|c|c|c|}
\hline $\begin{array}{c}\text { Tissue of } \\
\text { Origin }\end{array}$ & Transplanted Cells & $\begin{array}{l}\text { Transplantation } \\
\text { Strategy }\end{array}$ & Engraftment And Migration ${ }^{(1)}$ & Neuromarkers & Phenotypic Effects ${ }^{(2)}$ & Reference \\
\hline hNSC & hNSC & \begin{tabular}{|c|} 
mouse model: \\
pilocarpine \\
how many: \\
$5 \times 10^{6}$ cells in $500 \mu \mathrm{l}$
\end{tabular} & $\begin{array}{l}42 \text { DAT }^{(3)} \text { : cells found in CA1, } \\
\text { hilus, dentate gyrus, CA3, } \\
\text { amygdala and piriform cortex }\end{array}$ & $\begin{array}{l}42 \text { DAT: } 26 \% \text { GABA+; } 2 \% \\
\text { GluR }_{2}+; 2 \% \text { GFAP+ }\end{array}$ & $\begin{array}{l}1 \mathrm{MAT} \text { (4): increase of GABA inhibition; } \\
\text { reduction of seizure frequency, } \\
\text { duration and severity }\end{array}$ & 31 \\
\hline LGE & GABAergic progenitors & $\begin{array}{l}\text { mouse model: } \\
\text { kainic acid } \\
\text { how many: } \\
8 \times 10^{4} \text { cell } / \mu \mathrm{l} / \mathrm{site}\end{array}$ & $\begin{array}{l}12 \text { MAT: cells found partly } \\
\text { inside the hippocampus and } \\
\text { partly in the lateral ventricle }\end{array}$ & $\begin{array}{c}\text { 12MAT: } 69 \% \mathrm{GABA}+(30 \% \\
\mathrm{CB}+, 29 \% \mathrm{PV}+, 31 \% \mathrm{CR}+ \\
\text { and } 8 \% \mathrm{NPY}+)\end{array}$ & 9-12 MAT: $67-89 \%$ reduced seizures & 117 \\
\hline MGE & MGE progenitors & $\begin{array}{c}\text { mouse model: } \\
\text { pilocarpine } \\
\text { how many: } \\
3 \times 10^{4} \text { cells/injection }\end{array}$ & $\begin{array}{l}7 \text { DAT: MGE-cells migration; } \\
60 \text { DAT: cells localized in } \\
\text { host inhibitory local circuits; } \\
\text { functional integration into } \\
\text { hippocampal network } \\
\text { (spontaneous excitatory post- } \\
\text { synaptic currents) }\end{array}$ & $\begin{array}{c}2 \text { MAT: } 92 \% \text { NeuN+; } 63 \% \\
\text { GAD67+; } 41 \% \text { SST+; } 21 \% \\
\text { NOS+; } 7.7 \% \text { PV+; } 1.8 \% \\
\text { olig2+; } 1 \% \text { GFAP+ }\end{array}$ & $\begin{array}{l}60 \text { DAT: } 92 \% \text { reduced seizure } \\
\text { frequency and behavioral } \\
\text { comorbidities }\end{array}$ & 115 \\
\hline MGE & MGE progenitors & $\begin{array}{c}\text { mouse model: } \\
\text { pilocarpine } \\
\text { how many: } \\
3 \times 10^{4} \text { cells } / \text { injection }\end{array}$ & $\begin{array}{l}210 \text { DAT: MGE-cells migration; } \\
270 \text { DAT: functional integration } \\
\text { into hippocampal network } \\
\text { (spontaneous excitatory post- } \\
\text { synaptic currents) }\end{array}$ & $\begin{array}{c}\text { 6-7-12 MAT: Tuj1+; } \\
\text { GA67+; SST+, PV+, NOS+ }\end{array}$ & $\begin{array}{l}\text { 2-6-12 MAT: increase of GABA } \\
\text { inhibition; reduced seizure frequency, } \\
\text { rescue of behavioral deficits }\end{array}$ & 118 \\
\hline MGE & $\begin{array}{l}\text { MGE-derived } \\
\text { neurospheres (GF): } \\
2,7 \% \text { bTub }+; 20-30 \% \\
\text { GFAP-Nestin }\end{array}$ & $\begin{array}{l}\text { mouse model: } \\
\text { pilocarpine } \\
\text { how many: } \\
400 \text { cells } / 4 \mu l \text { per } \\
\text { animal }\end{array}$ & $\begin{array}{l}120 \text { DAT: migration in DG and } \\
\text { CA1 }\end{array}$ & $\begin{array}{c}120 \text { DAT: } 1,9 \% \text { NPY+; } 2,4 \\
\% \text { PV+; } 0,7 \% \text { CR+; } 5,6 \% \\
\text { GFAP+ }\end{array}$ & $\begin{array}{l}90 \text { DAT: } \\
\text { reduced seizure frequency (glia- } \\
\text { mediated) }\end{array}$ & 119 \\
\hline MGE & $\begin{array}{c}\text { MGE-derived } \\
\text { neurospheres (GF-RA): } \\
\text { 20\% } \beta \text { Tub; } 10 \% \text { GFAP } \\
30 \% \text { nestin }\end{array}$ & $\begin{array}{c}\text { mouse model: } \\
\text { pilocarpine } \\
\text { how many: } \\
400 \text { cells } / 4 \mu l \text { per } \\
\text { animal }\end{array}$ & $\begin{array}{l}120 \text { DAT: migration in DG and } \\
\text { CA1 }\end{array}$ & $\begin{array}{l}120 \text { DAT: } 1,5 \% \text { NPY+; } 2 \% \\
\text { PV+; } 3,4 \% \text { CR+; } 3 \% \text { GFAP+ }\end{array}$ & $\begin{array}{c}90 \text { DAT: no anticonvulsant effects and } \\
\text { lower cell-survival rate }\end{array}$ & 119 \\
\hline MGE & MGE progenitors & $\begin{array}{l}\text { mouse model: } \\
\text { pilocarpine } \\
\text { how many: } \\
400 \text { cells } / 4 \mu l \text { per } \\
\text { animal }\end{array}$ & $\begin{array}{l}120 \text { DAT: migration in DG and } \\
\text { CA1 }\end{array}$ & $\begin{array}{c}120 \text { DAT: } 12 \% \text { NPY+; } 7 \% \\
\text { PV+; } 6 \% \text { CR+; } 0,7 \% \text { GFAP+ }\end{array}$ & $\begin{array}{l}90 \text { DAT: } \\
\text { reduced seizure frequency (IN- } \\
\text { mediated) }\end{array}$ & 119 \\
\hline hESC & MGE-like progenitors & $\begin{array}{l}\text { mouse model: } \\
\text { pilocarpine } \\
\text { how many: } \\
5 \times 10^{4} \text { cells in a } 0.5 \\
\mu 1 / \text { site }\end{array}$ & $\begin{array}{l}14 \text { DAT and 4MAT: migration; } \\
2-5 \text { MAT: integration into } \\
\text { hippocampal network }\end{array}$ & $\begin{array}{c}\text { 14DAT: 80\% GABA+ } \\
\text { (Nkx2.1; NeuN+; Lhx6); } \\
\text { 4 MAT: 80\% GABA+ } \\
\text { (Nkx2.1; Sox6; Lhx6; SST; } \\
\text { CB; PV; CR; NPY; VIP); }\end{array}$ & $\begin{array}{l}3 \text { MAT: reduced seizure frequency } \\
\text { and rescue of behavioral deficits, of } \\
\text { GABA release and induced inhibitory } \\
\text { postsynaptic responses in host } \\
\text { neurons; excitatory synaptic inputs } \\
\text { from host glutamatergic neurons }\end{array}$ & 93 \\
\hline hiPSC & MGE-like progenitors & $\begin{array}{l}\text { mouse model: } \\
\text { kainic acid } \\
\text { how many: } \\
\text { 8-10 } 1010^{4} \text { cells/ } \\
\mu \mathrm{l} / \text { site }\end{array}$ & $\begin{array}{c}5 \text { MAT: proliferation and } \\
\text { migration in DG, CA1 and CA3 } \\
\text { Integration into hippocampal } \\
\text { network (formation of } \\
\text { synapses between transplanted } \\
\text { and host excitatory neurons) }\end{array}$ & $\begin{array}{c}5 \text { MAT: } 86 \% \text { NeuN+: } 76 \% \\
\text { GABA+ }(27 \% \text { PV+, } 11 \% \\
\text { NPY+) }\end{array}$ & $\begin{array}{l}5 \text { MAT: reduced seizure frequency, } \\
\text { duration and severity; reduced } \\
\text { anhedonia and cognitive deficits }\end{array}$ & 112 \\
\hline MGE & NSC & $\begin{array}{c}\text { mouse model: } \\
\text { kainic acid } \\
\text { how many: } \\
8-10 \times 10^{4} \text { cells/ } \\
\mu \mathrm{l} / \text { site }\end{array}$ & migration in DG & $\begin{array}{c}\text { NeuN+; GABA+; GFAP+; } \\
\text { NG2+ }\end{array}$ & $\begin{array}{l}\text { reduced seizure frequency, duration } \\
\text { and severity }\end{array}$ & 107 \\
\hline
\end{tabular}

(1): Effects of cells integration in host brain after transplantation. (2): Effects related to seizure and/or behavioral comorbidities. (3): DAT: days after transplantation. (4): MAT: months after transplantation.

Table 2: Grafting approaches in the neocortex.

\begin{tabular}{|c|c|c|c|c|c|c|}
\hline Starting cells & Transplanted cells & Transplantation strategy & Engraftment and migration ${ }^{(1)}$ & Neuromarkers & Phenotypic Effects ${ }^{(2)}$ & Reference \\
\hline MGE & MGE progenitors & $\begin{array}{l}\text { mouse model: WT } \\
\text { how many: } \\
4 \times 10^{5} \text { cells } / \text { mouse }\end{array}$ & $\begin{array}{c}30-40 \text { DAT }{ }^{(3)} \text { : cells dispersed } \\
\text { in cortex and integrated in the } \\
\text { network }\end{array}$ & $\begin{array}{l}30 \text { DAT: GABA+; } \\
\text { GAD67+; CR+; PV+; } \\
\text { NPY+; SST+ }\end{array}$ & $\begin{array}{c}1 \mathrm{MAT}(4) \text { : MGE-derived } \\
\text { neurons receive inputs } \\
\text { from host brain neurons, } \\
\text { establish synaptic contact } \\
\text { with dendrites of host } \\
\text { neurons }\end{array}$ & 110 \\
\hline hPSCs & MGE-like progenitors & $\begin{array}{c}\text { mouse model: } \\
\text { WT } \\
\text { how many: } \\
1-10 \times 10^{4} \text { cells/ injection site }\end{array}$ & $\begin{array}{l}\text { 6-7 MAT: } \\
\text { cells migrated and integrated } \\
\text { in the cortex; received } \\
\text { synaptic inputs, generated } \\
\text { GABAergic synaptic output }\end{array}$ & $\begin{array}{c}6 \mathrm{MAT}: 53 \% \text { LHX6+; } \\
51 \% \text { GABA+; } 61 \% \mathrm{CB}+; \\
72 \% \mathrm{CR}+; 50 \% \text { SST+ } \\
\text { and rare PV+ }\end{array}$ & N/A & 92 \\
\hline MGE & MGE progenitors & $\begin{array}{c}\text { mouse model: } \\
\text { Kv1.1 } 1^{-1-} \text { mice } \\
\text { how many: } \\
4 \times 10^{5} \text { cells } / \text { mouse }\end{array}$ & $\begin{array}{l}\text { 30-40 DAT: } \\
\text { cells dispersed in cortex and } \\
\text { integrated in the network }\end{array}$ & $\begin{array}{c}30 \text { DAT: } 65 \% \text { GABA+; } \\
29 \% \text { PV+; } 44 \% \text { SOM+; } \\
10 \% \text { NPY+; } 5 \% \text { CR+ }\end{array}$ & $\begin{array}{c}1 \text { MAT: reduced seizure } \\
\text { activity }\end{array}$ & 110 \\
\hline
\end{tabular}




\begin{tabular}{|c|c|c|c|c|c|c|}
\hline MGE & MGE progenitors & $\begin{array}{c}\text { mouse model: } \\
\text { MES } \\
\text { how many: } \\
5 \times 10^{4} \text { cells } / \text { mouse }\end{array}$ & $\begin{array}{c}60 \text { DAT: } \\
\text { cells migrated to cortex, } \\
\text { hippocampus, striatum, SVZ, } \\
\text { corpus callosum }\end{array}$ & $\begin{array}{c}60 \text { DAT: NPY+; CR+; } \\
\text { PV+ }\end{array}$ & $\begin{array}{c}60 \text { DAT: protection against } \\
\text { tonic seizures and reduced } \\
\text { mortality rate }\end{array}$ & 120 \\
\hline MGE & $\begin{array}{l}\text { MGE-derived } \\
\text { neurospheres }\end{array}$ & $\begin{array}{c}\text { mouse model: } \\
\text { PTZ and MES } \\
\text { how many: } \\
5-15 \times 10^{4} \text { cells in } 0.4 \mu \mathrm{l}\end{array}$ & $\begin{array}{c}60 \text { DAT: } \\
\text { cell migrated to piriform } \\
\text { cortex, fimbria and ventricular } \\
\text { wall }\end{array}$ & 60 DAT: PV+ & $\begin{array}{l}2 \text { MAT: protection against } \\
\text { PTZ-induced seizures, but } \\
\text { not against MES-induced } \\
\text { seizures. }\end{array}$ & 121 \\
\hline
\end{tabular}

(1): Effects of cells integration in host brain after transplantation. (2): Effects related to seizure and/or behavioral comorbidities. (3): DAT: days after transplantation. (4): MAT: months after transplantation.

phenotype. The authors reported a $92 \%$ reduction in seizure frequency but no rescue of aberrant mossy fiber sprouting, in accordance with previous results [115]. The therapeutic effects were analyzed only in a two-month time scale.

Adopting a similar experimental paradigm, another study used freshly dissociated MGE-derived progenitors grafted in a model of pilocarpin-induced seizure, and monitored the effect at 7 and 12 months after transplantation [118]. At 7 months, the grafted cells were differentiated into GAD67 $7^{+}$neurons expressing SST, PV and nNOS (Table 1). Two months after grafting, the animals showed seizures suppression and rescue of behavioral comorbidities; at 6 months seizures frequency was reduced by $84 \%$ and at 12 months the seizures total number was reduced by $88 \%$. The authors also documented enhancement of GABAergic IN-mediated currents suggesting a functional integration in the host network [118].

In a recent study, MGE-derived dissociated progenitor cells were used in grafting experiments and compared to MGE-derived neurospheres for their anticonvulsant effects in a model of pilocarpine-induced TLE [119]. Specifically, the authors compared three in vitro states of the grafted cells: fresh MGE-cells; MGE-derived neurospheres cultured with growth factors and retinoic acid (GF-RA group); or the same cultured without retinoic acid (GF group). While the GF-RA group resulted in increased neuronal population in vitro, only the GF-neurospheres and freshly dissociated MGE cells showed anticonvulsant activity. Both groups showed reduced seizure frequency 3 months after the grafting, but apparently by different mechanisms: GF-neurospheres efficiently differentiated into INs and glial cells with equal efficiency, freshly dissociated MGE cells mainly differentiated into INs, with only $0.7 \%$ of $\mathrm{GFAP}^{+}$cells (Table 1 ). Thus, the anticonvulsant effects of GF-neurospheres seems to be glialmediated, while freshly dissociated MGE cells appear more appropriates for cell-therapy treatment of epilepsy, targeting the inhibitory circuitry [119]. In this study only short-term effects were examined, and cell differentiation, senescence and survival were not assessed on the long-term.

On the whole, these studies indicate that grafted embryonic MGE cells are effective in reducing seizure frequency, duration and severity, as well as in alleviating behavioral co-morbidities. However, for clinical application cells sources must be standardized, well characterized, quality-controlled and unlimited in supply. For these reasons and for strong ethical issues, human embryonic MGE-cells cannot be routinely exploited. To overcome this limit, human iPSC have been tested as a valid and promising alternative. hiPSC-derived GABAergic INs were shown to be able to migrate and integrate into dysfunctional circuitry in mice with pilocarpine-induced TLE, and to generate inhibitory postsynaptic responses in host hippocampal neurons [93]. Two weeks post transplantation, grafted cells were found to primarily cluster near the injection site, with nearly $80 \%$ of cells expressing GABA, and a large fraction of these scoring positive for Nkx2.1, NeuN and Lhx6 (Table 1). Four months post-injection hiPSC-derived INs had migrated and integrated in the host circuitry, without significant differences in the total number of surviving cells. At this time-point, $80 \%$ of the grafted cells were bona-fide GABAergic INs (expressing Nkx2.1, Sox6, Lhx6 and GABA) and scored positive for the subtype-specific markers SST, CB, PV, CR, NPY and VIP (Table 1). All transplanted cells showed reduced positivity for glial markers, suggesting a proper IN differentiation. Overall, the approach suppressed seizures and ameliorated behavioral abnormalities, providing a first evidence of hiPSC application in the management of intractable epilepsy [93]. Similar results were recently published using hiPSC-derived MGE-like progenitor cells transplanted into the hippocampi of KA-treated rats [112]. The authors found that the grafted cells proliferate immediately after grafting, then migrate into DG, CA1 and CA3 subfields, were they differentiated in GABAergic INs with high efficiency (80\%) and integrate into the host network forming synapses with excitatory neurons. The grafting resulted in reduction of aberrant neurogenesis, and a significative reduction of seizure frequency, duration and severity, as well as anhedonia and cognitive disfunctions [112].These effects, however, were analysed only in the short-term.

In summary, current data show that MGE-derived cells efficiently migrate and differentiate into GABAergic INs, able to functionally integrate in the host brain network when transplanted into the hippocampus of various models of epilepsy. The overall effect is a reduction of seizures occurrence and severity, associated with increase inhibitory activity. We should note, however, that most of the published studies observe cell and phenotypes in the short-term, while long-term analyses are very limited. Furthermore, all studies adopt a pharmacological induction of SE, which is difficult to relate this to epilepsy in human, characterized by spontaneous seizures caused by a combination of genetic and environmental factors. 
Neocortex: The epileptic brain is characterized by a disfunction in excitatory-inhibitory balance that also involves the neocortex [50]. Thus, several studies focused on the effects of cell grafting directly into the cortex and the effect of this procedure on cortical circuity. The main results are summarized in table 2 .

In an early study, MGE progenitor cells were dissociated from embryonic MGE and bilaterally transplanted into the cortex of wild-type mice; one month after transplantation cells were found to be migrated and dispersed in the host cortex and differentiated into GABAergic INs and their subclasses, the largest proportions being $\mathrm{PV}^{+}$and $\mathrm{SST}^{+}$[110] (Table 2). Grafted cells, specifically starting from 7-10 days after grafting, acquired intrinsic membrane properties of immature INs and 30-40 days after transplantation an increased inhibition of II/ III layers pyramidal neurons was shown, while not changes in inhibition by host INs. This potentiation of inhibition involves postsynaptic GABA receptors and provides evidence that grafted cells integrate in brain circuits, receive inputs from host brain neurons and form synaptic contacts onto their dendrites primarily targeting excitatory pyramidal neurons [110].

In a subsequent study, hiPSC-derived MGE-like cells were grafted into the cortex of newborn SCID (severe combined immunodeficient) mice, and monitored thereafter [92]. The results show that these MGE-like cells survived in the brain after 2, 4 and 7 months, with an average surviving rate of $5 \%, 3 \%$ and $8 \%$ respectively. Two months post-injection grafted cells were found to proliferate and to express the immature neuroblast marker $\mathrm{DCX}^{+}$, while at 3 and 7 months post-injection cells had migrated in the cortex. By 7 months post-injection, the grafted cells were seen to express NeuN, a marker of more mature neurons. From a functional point of view, mature hiPSC-derived INs fired subtype-specific trains of action potentials, received synaptic inputs, generated GABAergic-exclusive synaptic output, and functionally integrated into the rodent cortex [92].

Three main types of animal models of cortical epilepsy have been used to test the efficacy of cell-based strategies: a) genetically induced, b) induced by maximal electroshock (MES), c) induced by pharmacological treatment with pentylenetetrazole (PTZ).

a) the most used genetic model of cortical epilepsy is the Kv1.1/Kcna1 mutant mouse strain; these animals lack a shaker-like potassium channel and mimic a neuronal ion channelopathy associated with epilepsy in humans [110]. Freshly dissociated MGE progenitors were grafted into the cerebral cortex of P2 Kv1.1/Kcna1 mutant mice resulting in a reduced frequency and duration of spontaneous EEG seizures 2 months after transplantation. Almost $65 \%$ of grafted cells differentiated in GABAergic INs, and expressed the subtypespecific markers PV, SST, NPY and CR [110]. b) the maximal electroshock (MES) model relies on the application of an alternating current causes a generalized tonic-clonic seizures $[120,121]$. Adopting this model, freshly dissociated MGE progenitors transplanted into the brain cortex 2 months after MES-induced seizure were shown to protect against tonic seizures and reduce the mortality rate [120]. On the contrary, cells dissociated from the MGE but then maintained and expanded in vitro as floating neurospheres showed strikingly different results in the MES model: unlike freshly dissociated MGE cells, neurosphereexpanded progenitors had no effects on seizures frequency [121], despite both experimental groups used a comparable number of cells injected bilaterally in the cortex. Thus, in the MES model transplantation of precursors dissociated directly from MGE is more efficient in reducing frequency and intensity of tonic seizures.

From a cellular point of view, in both studies, two months after injection grafted cells efficiently survived, migrated and differentiated into INs. However, the migration sites are different between these studies: Calcagnotto and colleagues found grafted cells in cortex, hippocampus, striatum, subventricular zone and corpus callosum, while Paiva and colleagues found INs throughout the brain parenchyma (piriform cortex, fimbria, and ventricular zone). Moreover, Paiva and colleagues examined only the $\mathrm{PV}^{+}$cells, while Calcagnotto and colleagues evaluated the morphology and the expression of more IN markers including $\mathrm{NPY}^{+}, \mathrm{CR}^{+}$and $\mathrm{PV}^{+}$cells $[120,121]$.

c) The pharmacological model based on treatment with pentylenetetrazole (PTZ) induces clonic or tonic-clonic seizures, by acting on GABA-A receptors and impairing local inhibition. Grafting of MGE progenitors maintained as neurospheres in the neocortex of PTZ-treated animals resulted in a protective effect from seizure $[120,121]$. These grafted cells showed a high rate of survival and of $\mathrm{PV}^{+}$differentiation as compared to the same cells transplanted into mice that underwent MES [121].

Based on the available results, it can be concluded that neural progenitors maintained as neurospheres are not ideal, as compared to fresh isolated or in vitro-expanded progenitors from MGE. However, this seriously hampers the applications in human therapy, due to the limited availability of fetal tissues.

\section{Concluding remarks and perspectives}

The reported studies show that MGE-derived cells efficiently migrate and differentiate into GABAergic INs, able to functionally integrate in the host brain network when transplanted into hippocampus or cortex of various models of epilepsy. The overall effect is a reduction of seizures occurrence and severity. Electrophysiological recordings reveal that exogenous INs functionally integrate in the host circuity providing increased inhibitory activity, although not all authors investigated this aspect. Importantly, the 
anticonvulsant efficacy of grafted cells seems to largely depend on the mode of collecting and expanding these cells: whether from primary dissociated MGE embryonic tissues $[110,115,118-120]$, from neurosphere-expanded MGE progenitors [119,121], from differentiated hIPSC [92,93,112], or from hNSC [31]. Among these, the use of dissociated MGE cells seems to be the most valid and applied strategy. Studies on differentiation and transplantation of hiPSC-derived cells are likely to lead to significant improvements in the next few years.

Concerning the translation to the human setting, one issue that has to be taken into account is the animal model of epilepsy or TLE that have been used so far. Models of epilepsy induced by drugs, although easily standardized and quantifiableand thus adopted in scientific studies -only partially and imprecisely represent human conditions. In alternative, genetic models in rodents (knock-out or transgenic), in which congenital chronic epileptic syndromes result from a known inherited genetic lesion, have been introduced [65]. Although these are certainly closer to reality, the issue that emerges is the existence of numerous, rare epileptic syndromes, with quite distinct and peculiar phenotypic manifestations. Each genetic model will only represent a single and specific human condition, certainly not the full spectrum and not the majority of conditions, which are rather sporadic or with multigenic risk determinants.

Most studies have demonstrated survival and differentiation of the grafted cells in the short- or medium-term (2-6 months), but not in the long-term; with the exception of two studies that prolonged the analyses to 12 months $[117,118]$. Information on long-term cell survival, differentiation and circuit integration is the next important step, in order to better evaluate the translation value of these experimental therapies in view of future clinical applications and to understand if they have a transient short-term effect or a long-term efficacy. In the perspective of clinical trials, a transient therapeutic effect is clearly insufficient.

The follow up of the grafted progenitors or the immature INs, monitoring their proliferation, stability of the differentiated phenotype, senescence and apoptosis, is another key task. In the rodent brain cells labeled with fluorescent markers can be used for in vivo imaging, and single neurons can be visualized and subjected to neuro chemical and electrophysiological analyses. The $\mathrm{PV}^{+}$and $\mathrm{SST}^{+}$neurons are the most studied ones, however the repertoire of IN subtypes is much wider, and the contribution and/or involvement of each of these in seizure is not fully known. Upon grafting, we are currently unable to monitor all IN subtypes, and consequently their survival, senescence and differentiation is not really known. It is likely that we are still missing some important contribution, and this could also be the reason for discrepancies in the results from lab to lab.
Likewise, which and how each IN subtype participates and contributes to epilepsy is not fully understood. Although $\mathrm{PV}^{+}$neurons appear to be more directly implicated and are observed after grafting, this could simply reflect the fact that they are mostly studied as compared to other types. If we knew better which types participate and how, we could adopt in vitro procedures that can be able to lead and expand that kind of progenitors, avoiding unnecessary mix of cells. A deeper knowledge of the main actors in the epilepsy's seizure context would be necessary to develop a better and more specific therapeutic approach. This could in principle be done using optogenetic methods, which these consents to activate or inihibit specific subpopulation of neurons in vivo with unprecedented time-resolution [60].

In parallel, strong efforts in basic and applied research on neural progenitor cells are needed to fully unravel the differentiation trajectory of each IN subtypes in vitro $[11,86]$ and to optimize expansion and differentiation protocols aimed to obtain the specific IN subclass required, reliably and reproducibly. One important advancement will be the development of human cell models of seizure, either deriving hiPSC from patients carrying known mutation in epilepsyrelevant genes, or introducing the same mutations via genome editing (CRISPR-cas9). These cells could then be used in research (set up mixed cultures of excitatory and inhibitory neurons or mixed cortical and basal brain organoid). Once validated, these cells could open to way to screening efforts for the search of novel compounds.

\section{Acknowledgment}

This review was supported by the IRMI Italian Regenerative Medicine Infrastructure program (Italian Ministry of Health CTN01 00177 88744) and by Università di Torino (RiLO, Ricerca Locale).

\section{Author contributions}

All the authors contributed parts of the original text. $\mathrm{LC}$ and GRM outlined and revised the manuscript and coordinated the writing.

\section{References}

1. Chang BS, Lowenstein DH. Epilepsy. N Engl J Med. 2003; 349: 12571266.

2. Galanopoulou AS. Mutations affecting GABAergic signaling in seizures and epilepsy. Pflüg Arch. Eur J Physiol. 2010; 460: 505-523. PubMed: https://www.ncbi.nlm.nih.gov/pubmed/20352446

3. Goodwin M. The importance of brand continuity in epilepsy drugs. Nurs Times. 2005; 101: 26-27.

PubMed: https://www.ncbi.nlm.nih.gov/pubmed/15997944

4. Herman S. Intractable Epilepsy: Relapsing, Remitting, or Progressive? Epilepsy Curr. 2010; 10: 146-148.

PubMed: https://www.ncbi.nlm.nih.gov/pmc/articles/PMC3001022/

5. Walia KS, Khan EA, Ko DH, Raza SS, Khan YN. Side Effects of Antiepileptics- A Review. Pain Pract. 2004; 4: 194-203.

PubMed: https://www.ncbi.nlm.nih.gov/pubmed/17173601 
6. Zhu Q, Naegele JR, Chung S. Cortical GABAergic Interneuron/ Progenitor Transplantation as a Novel Therapy for Intractable Epilepsy. Front Cell Neurosci. 2018; 12: 167.

PubMed: https://www.ncbi.nlm.nih.gov/pubmed/29997478

7. Hovinga CA, Asato MR, Manjunath R, Wheless JW, Phelps SJ, et al. Association of non-adherence to antiepileptic drugs and seizures, quality of life, and productivity: Survey of patients with epilepsy and physicians. Epilepsy Behav. 2008; 13: 316-322.

PubMed: https://www.ncbi.nlm.nih.gov/pubmed/18472303

8. Southwell DG, Nicholas CR, Basbaum Al, Stryker MP, Kriegstein AR, et al. Interneurons from Embryonic Development to Cell-Based Therapy. Science. 2014; 344: 1240622-1240622

9. Markram H, Toledo-Rodriguez M, Wang Y, Gupta A, Silberberg G, et al. Interneurons of the neocortical inhibitory system. Nat Rev Neurosci. 2004; 5: 793-807.

10. The Petilla Interneuron Nomenclature Group (PING), Ascoli GA, AlonsoNanclares L, Anderson SA, Barrionuevo G, et al. Petilla terminology: nomenclature of features of GABAergic interneurons of the cerebral cortex. Nat Rev Neurosci. 2008; 9: 557-568.

PubMed: https://www.ncbi.nlm.nih.gov/pubmed/18568015

11. Tasic B, Menon V, Nguyen TN, Kim TK, Jarsky T, et al. Adult mouse cortical cell taxonomy revealed by single cell transcriptomics. Nat Neurosci. 2016; 19: 335-346.

PubMed: https://www.ncbi.nlm.nih.gov/pubmed/26727548

12. Kelsom C, Lu W. Development and specification of GABAergic cortical interneurons. Cell Biosci. 2013; 3: 19.

PubMed: https://www.ncbi.nlm.nih.gov/pubmed/26727548

13. The Petilla Interneuron Nomenclature Group (PING), Ascoli GA, AlonsoNanclares L, Anderson SA, Barrionuevo G, et al. Petilla terminology: nomenclature of features of GABAergic interneurons of the cerebral cortex. Nat Rev Neurosci. 2008; 9: 557-568.

PubMed: https://www.ncbi.nlm.nih.gov/pubmed/18568015

14. Zeisel A, Munoz-Manchado AB, Codeluppi S, Lonnerberg P, La Manno $\mathrm{G}$, et al. Cell types in the mouse cortex and hippocampus revealed by single-cell RNA-seq. Science. 2015; 347: 1138-1142.

PubMed: https://www.ncbi.nlm.nih.gov/pubmed/25700174

15. Toledo-Rodriguez $M$, Markram H. Single-cell RT-PCR, a technique to decipher the electrical, anatomical, and genetic determinants of neuronal diversity. Methods Mol Biol. 2014; 1183: 143-158. PubMed: https://www.ncbi.nlm.nih.gov/pubmed/25023306

16. Mi D, Li Z, Lim L, Li M, Moissidis M, et al. Early emergence of cortical interneuron diversity in the mouse embryo. Science. 2018; 360: 81-85. PubMed: https://www.ncbi.nlm.nih.gov/pubmed/29472441

17. Anderson SA. Interneuron Migration from Basal Forebrain to Neocortex: Dependence on Dlx Genes. Science. 1997; 278: 474-476.

PubMed: https://www.ncbi.nlm.nih.gov/pubmed/9334308

18. Brunstrom JE, Gray-Swain MR, Osborne PA, Pearlman AL. Neuronal heterotopias in the developing cerebral cortex produced by neurotrophin-4. Neuron. 1997; 18: 505-517.

PubMed: https://www.ncbi.nlm.nih.gov/pubmed/9115743

19. de Carlos JA, López-Mascaraque L, Valverde F. Dynamics of cell migration from the lateral ganglionic eminence in the rat. $J$ Neurosci. 1996; 16: 6146-6156.

PubMed: https://www.ncbi.nlm.nih.gov/pubmed/8815897

20. DeDiego I, Smith-Fernández A, Fairén A. Cortical cells that migrate beyond area boundaries: characterization of an early neuronal population in the lower intermediate zone of prenatal rats. Eur $\mathrm{J}$ Neurosci. 1994; 6: 983-997.

PubMed: https://www.ncbi.nlm.nih.gov/pubmed/7952285
21. Tamamaki N, Fujimori KE, Takauji R. Origin and route of tangentially migrating neurons in the developing neocortical intermediate zone. $J$ Neurosci. 1997; 17: 8313-8323.

PubMed: https://www.ncbi.nlm.nih.gov/pubmed/9334406

22. Butt SJB, Fuccillo M, Nery S, Noctor S, Kriegstein A, et al. The Temporal and Spatial Origins of Cortical Interneurons Predict Their Physiological Subtype. Neuron. 2005; 48: 591-604.

PubMed: https://www.ncbi.nlm.nih.gov/pubmed/16301176

23. Gelman DM, Martini FJ, Nobrega-Pereira S, Pierani A, Kessaris N, et al The Embryonic Preoptic Area Is a Novel Source of Cortical GABAergic Interneurons. J Neurosci 2009; 29: 9380-9389.

PubMed: https://www.ncbi.nlm.nih.gov/pubmed/19625528

24. Xu Q. Origins of Cortical Interneuron Subtypes. J Neurosci. 2004; 24: 2612-2622.

PubMed: https://www.ncbi.nlm.nih.gov/pubmed/15028753

25. Xu Q, Tam M, Anderson SA. Fate mapping Nkx2.1-lineage cells in the mouse telencephalon. J Comp Neurol. 2008; 506: 16-29. PubMed: https://www.ncbi.nlm.nih.gov/pubmed/17990269

26. Tanaka DH, Oiwa R, Sasaki E, Nakajima K. Changes in cortical interneuron migration contribute to the evolution of the neocortex. Proc Natl Acad Sci. 2011; 108: 8015-8020.

27. Clowry GJ. An enhanced role and expanded developmental origins for gamma-aminobutyric acidergic interneurons in the human cerebral cortex. J Anat. 2015; 227: 384-393.

PubMed: https://www.ncbi.nlm.nih.gov/pubmed/24839870

28. Hansen DV, Lui JH, Flandin P, Yoshikawa $\mathrm{K}$, Rubenstein $\mathrm{JL}$, et al Non-epithelial stem cells and cortical interneuron production in the human ganglionic eminences. Nat Neurosci. 2013; 16: 1576-1587. PubMed: https://www.ncbi.nlm.nih.gov/pubmed/24097039

29. Al-Jaberi N, Lindsay S, Sarma S, Bayatti N, Clowry GJ. The Early Fetal Development of Human Neocortical GABAergic Interneurons. Cereb Cortex. 2015; 25: 631-645.

PubMed: https://www.ncbi.nlm.nih.gov/pubmed/24047602

30. Ma T, Wang $C$, Wang L, Zhou X, Tian M, et al. Subcortical origins of human andmonkeyneocorticalinterneurons. NatNeurosci.2013;16:1588-1597. PubMed: https://www.ncbi.nlm.nih.gov/pubmed/24097041

31. Chu K, Kim M, Jung KH, Jeon D, Lee ST, et al. Human neural stem cell transplantation reduces spontaneous recurrent seizures following pilocarpine-induced status epilepticus in adult rats. Brain Res. 2004 1023: 213-221.

PubMed: https://www.ncbi.nlm.nih.gov/pubmed/15374747

32. Kepecs A, Fishell G. Interneuron cell types are fit to function. Nature. 2014; 505: 318-326.

PubMed: https://www.ncbi.nlm.nih.gov/pubmed/24429630

33. Klausberger T, Somogyi P. Neuronal Diversity and Temporal Dynamics: The Unity of Hippocampal Circuit Operations. Science. 2008; 321: 53-57. PubMed: https://www.ncbi.nlm.nih.gov/pubmed/18599766

34. Jiang $X$, Shen $S$, Cadwell CR, Berens $P$, Sinz F, et al. Principles of connectivity among morphologically defined cell types in adult neocortex. Science. 2015; 350: aac9462-aac9462.

PubMed: https://www.ncbi.nlm.nih.gov/pubmed/26612957

35. Traub RD, Borck C, Colling SB, Jefferys JGR. On the Structure of Ictal Events in Vitro. Epilepsia. 1996; 37: 879-891.

PubMed: https://www.ncbi.nlm.nih.gov/pubmed/8814102

36. Traub RD, Whittington MA, Colling SB, Buzsáki G, Jefferys JG. Analysis of gamma rhythms in the rat hippocampus in vitro and in vivo. $J$ Physiol. 1996; 493: 471-484.

PubMed: https://www.ncbi.nlm.nih.gov/pubmed/8782110 
37. Curia G, Longo D, Biagini G, Jones RSG, Avoli M. The pilocarpine mode of temporal lobe epilepsy. J Neurosci Methods. 2008; 172: 143-157. PubMed: https://www.ncbi.nlm.nih.gov/pubmed/18550176

38. Scheffer IE, Berkovic S, Capovilla G, Connolly MB, French J, et al. ILAE classification of the epilepsies: Position paper of the ILAE Commission for Classification and Terminology. Epilepsia. 2017; 58: 512-521. PubMed: https://www.ncbi.nlm.nih.gov/pubmed/28276062

39. Avanzini G, Franceschetti S. Cellular biology of epileptogenesis. Lancet Neurol. 2003; 2: 33-42.

PubMed: https://www.ncbi.nlm.nih.gov/pubmed/12849299

40. Kann O, Kovács R. Mitochondria and neuronal activity. Am J Physiol Cell Physiol 2007; 292: C641-C657.

PubMed: https://www.ncbi.nlm.nih.gov/pubmed/17092996

41. Papageorgiou IE, Fetani AF, Lewen A, Heinemann U, Kann $O$. Widespread activation of microglial cells in the hippocampus of chronic epileptic rats correlates only partially with neurodegeneration. Brain Struct Funct. 2015; 220: 2423-2439.

PubMed: https://www.ncbi.nlm.nih.gov/pubmed/24878824

42. Seifert G, Carmignoto G, Steinhäuser C. Astrocyte dysfunction in epilepsy. Brain Res Rev. 2010; 63: 212-221.

PubMed: https://www.ncbi.nlm.nih.gov/pubmed/19883685

43. Bissonette GB, Bae MH, Suresh T, Jaffe DE, Powell EM. Prefrontal cognitive deficits in mice with altered cerebral cortical GABAergic interneurons. Behav Brain Res. 2014; 259: 143-151.

PubMed: https://www.ncbi.nlm.nih.gov/pubmed/24211452

44. Hashemi E, Ariza J, Rogers H, Noctor SC, Martínez-Cerdeño V. The Number of Parvalbumin-Expressing Interneurons Is Decreased in the Prefrontal Cortex in Autism. Cereb Cortex. 2018; 28: 690-690. PubMed: https://www.ncbi.nlm.nih.gov/pubmed/26922658

45. Inan M, Petros TJ, Anderson SA. Losing your inhibition: linking cortica GABAergic interneuronsto schizophrenia. NeurobiolDis. 2013;53:36-48. PubMed: https://www.ncbi.nlm.nih.gov/pubmed/23201207

46. Jacob J. Cortical interneuron dysfunction in epilepsy associated with autism spectrum disorders. Epilepsia. 2016; 57: 182-193.

PubMed: https://www.ncbi.nlm.nih.gov/pubmed/26682992

47. Konstantoudaki X, Chalkiadaki K, Tivodar S, Karagogeos D, Sidiropoulou K. Impaired synaptic plasticity in the prefrontal cortex of mice with developmentally decreased number of interneurons. Neuroscience. 2016; 322: 333-345.

PubMed: https://www.ncbi.nlm.nih.gov/pubmed/26926965

48. Ongür D, Prescot AP, McCarthy J, Cohen BM, Renshaw PF. Elevated gamma-aminobutyric acid levels in chronic schizophrenia. Biol. Psychiatry. 2010; 68: 667-670.

PubMed: https://www.ncbi.nlm.nih.gov/pmc/articles/PMC2942977/

49. Takano T. Interneuron Dysfunction in Syndromic Autism: Recent Advances. Dev Neurosci. 2015; 37: 467-475.

PubMed: https://www.ncbi.nlm.nih.gov/pubmed/26183392

50. Yizhar $\mathrm{O}$, Fenno LE, Prigge $\mathrm{M}$, Schneider $\mathrm{F}$, Davidson $\mathrm{TJ}$, et al Neocortical excitation/inhibition balance in information processing and social dysfunction. Nature. 2011; 477: 171-178.

PubMed: https://www.ncbi.nlm.nih.gov/pubmed/21796121

51. Yoon JH, Maddock RJ, Rokem A, Silver MA, Minzenberg MJ, et al GABA concentration is reduced in visual cortex in schizophrenia and correlates with orientation-specific surround suppression. J Neurosci. 2010; 30: 3777-3781.

PubMed: https://www.ncbi.nlm.nih.gov/pubmed/20220012

52. Marín O. Interneuron dysfunction in psychiatric disorders. Nat Rev Neurosci. 2012; 13: 107-120.

PubMed: https://www.ncbi.nlm.nih.gov/pubmed/22251963
53. Galanopoulou A. GABAA Receptors in Normal Development and Seizures: Friends or Foes? Curr Neuropharmacol. 2008; 6: 1-20. PubMed: https://www.ncbi.nlm.nih.gov/pmc/articles/PMC2645547/

54. Galanopoulou AS. Sexually dimorphic expression of KCC2 and GABA function. Epilepsy Res. 2008; 80: 99-113.

PubMed: https://www.ncbi.nlm.nih.gov/pubmed/18524541

55. Ben-Ari Y. Excitatory actions of gaba during development: the nature of the nurture. Nat Rev Neurosci. 2002; 3: 728-739.

PubMed: https://www.ncbi.nlm.nih.gov/pubmed/12209121

56. Kato M. Genotype-phenotype correlation in neuronal migration disorders and cortical dysplasias. Front Neurosci. 2015; 9: 181. PubMed: https://www.ncbi.nlm.nih.gov/pubmed/26052266

57. Cammarota M, Losi G, Chiavegato A, Zonta M, Carmignoto G. Fast spiking interneuron control of seizure propagation in a cortical slice model of focal epilepsy: Fast-spiking interneurons in focal seizure propagation. J Physiol. 2013; 591: 807-822.

PubMed: https://www.ncbi.nlm.nih.gov/pubmed/23207591

58. Sessolo M, Marcon I, Bovetti S, Losi G, Cammarota M, et al. ParvalbuminPositive Inhibitory Interneurons Oppose Propagation But Favor Generation ofFocalEpileptiformActivity.JNeurosci.2015;35:9544-9557. PubMed: https://www.ncbi.nlm.nih.gov/pubmed/26134638

59. Shiri Z, Manseau F, Lévesque M, Williams S, Avoli M. Interneuron activity leads to initiation of low-voltage fast-onset seizures: Epileptiform Synchronization. Ann Neurol. 2015; 77: 541-546. PubMed: https:// www.ncbi.nlm.nih.gov/pubmed/25546300

60. Ye H, Kaszuba S. Inhibitory or excitatory? Optogenetic interrogation of the functional roles of GABAergic interneurons in epileptogenesis. J Biomed Sci. 2017; 24: 93.

PubMed: https://www.ncbi.nlm.nih.gov/pubmed/29202749

61. Everson JL, Fink DM, Yoon JW, Leslie EJ, Kietzman HW, et al Sonic hedgehog regulation of Foxf2 promotes cranial neural crest mesenchyme proliferation and is disrupted in cleft lip morphogenesis. Development. 2017; 144: 2082-2091.

PubMed: https://www.ncbi.nlm.nih.gov/pubmed/28506991

62. Markram H, Toledo-Rodriguez $M$, Wang $Y$, Gupta A, Silberberg G, et al. Interneurons of the neocortical inhibitory system. Nat Rev Neurosci. 2004; 5: 793-807.

PubMed: https://www.ncbi.nlm.nih.gov/pubmed/15378039

63. Whittington MA, Traub RD. Interneuron Diversity series: Inhibitory interneurons and network oscillations in vitro. Trends Neurosci. 2003; 26: 676-682. PubMed: https://www.ncbi.nlm.nih.gov/ pubmed/14624852

64. Wang X-J, Tegnér J, Constantinidis C, Goldman-Rakic PS. Division of labor among distinct subtypes of inhibitory neurons in a cortical microcircuit of working memory. Proc Natl Acad Sci USA. 2004; 101: 1368-1373.

PubMed: https://www.ncbi.nlm.nih.gov/pubmed/14742867

65. Katsarou A-M, Moshé SL, Galanopoulou AS. Interneuronopathies and their role in early life epilepsies and neurodevelopmental disorders. Epilepsia Open. 2017; 2: 284-306.

PubMed: https://www.ncbi.nlm.nih.gov/pubmed/29062978

66. Reid CA, Berkovic SF, Petrou S. Mechanisms of human inherited epilepsies. Prog Neurobiol. 2009; 87: 41-57.

PubMed: https://www.ncbi.nlm.nih.gov/pubmed/18952142

67. de Lanerolle NC, Kim JH, Robbins RJ, Spencer DD. Hippocampal interneuron loss and plasticity in human temporal lobe epilepsy. Brain Res. 1989; 495: 387-395.

PubMed: https://www.ncbi.nlm.nih.gov/pubmed/2569920 
68. Poduri A, Lowenstein D. Epilepsy genetics-past, present, and future. Curr Opin Genet Dev. 2011; 21: 325-332.

PubMed: https://www.ncbi.nlm.nih.gov/pmc/articles/PMC4074083/

69. Tai C, Abe Y, Westenbroek RE, Scheuer T, Catterall WA. Impaired excitability of somatostatin- and parvalbumin-expressing cortical interneurons in a mouse model of Dravet syndrome. Proc Natl Acad Sci USA. 2014; 111: E3139-E3148.

PubMed: https://www.ncbi.nlm.nih.gov/pubmed/25024183

70. Ribak C, Bradurne R, Harris A. A preferential loss of GABAergic symmetric synapses in epileptic foci: a quantitative ultrastructura analysis of monkey neocortex. J Neurosci. 1982; 2: 1725-1735. PubMed: https://www.ncbi.nlm.nih.gov/pubmed/6815309

71. Moxon KA, Shahlaie K, Girgis F, Saez I, Kennedy J, et al. From adagio to allegretto: The changing tempo of theta frequencies in epilepsy and its relation to interneuron function. Neurobiol Dis. 2019; 129: 169-181. PubMed: https://www.ncbi.nlm.nih.gov/pubmed/30798003

72. Jiruska P, Alvarado-Rojas C, Schevon CA, Staba R, Stacey W, et al. Update on the mechanisms and roles of high-frequency oscillations in seizures and epileptic disorders. Epilepsia. 2017; 58: 1330-1339. PubMed: https://www.ncbi.nlm.nih.gov/pubmed/28681378

73. Kann 0. The interneuron energy hypothesis: Implications for brain disease. Neurobiol Dis. 2016; 90: 75-85.

PubMed: https://www.ncbi.nlm.nih.gov/pubmed/26284893

74. Ledri M, Madsen MG, Nikitidou L, Kirik D, Kokaia M. Global Optogenetic Activation of Inhibitory Interneurons during Epileptiform Activity. J Neurosci. 2014; 34: 3364-3377.

PubMed: https://www.ncbi.nlm.nih.gov/pubmed/24573293

75. Ladas TP, Chiang CC, Gonzalez-Reyes LE, Nowak T, Durand DM. Seizure reduction through interneuron-mediated entrainment using low frequency optical stimulation. Exp Neurol. 2015; 269: 120-132. PubMed: https://www.ncbi.nlm.nih.gov/pubmed/25863022

76. Balagura G, lapadre G, Verrotti A, Striano P. Moving beyond sodium valproate: choosing the right anti-epileptic drug in children. Expert Opin Pharmacother. 2019; 1-8.

PubMed: https://www.ncbi.nlm.nih.gov/pubmed/31099271

77. Franchi SA, Macco R, Astro V, Tonoli D, Savino E, et al. A Method to Culture GABAergic Interneurons Derived from the Medial Ganglionic Eminence. Front Cell Neurosci. 2018; 11: 423.

PubMed: https://www.ncbi.nlm.nih.gov/pubmed/29358905

78. Corti S, Faravelli I, Cardano M, Conti L. Human pluripotent stem cells as tools for neurodegenerative and neurodevelopmental disease modeling and drug discovery. Expert Opin Drug Discov. 2015; 10: 615-629. PubMed: https://www.ncbi.nlm.nih.gov/pubmed/25891144

79. Ding S, Schultz PG. A role for chemistry in stem cell biology. Nat Biotechnol. 2004; 22: 833-840.

PubMed: https://www.ncbi.nlm.nih.gov/pubmed/15229546

80. Ding S, Wu TYH, Brinker A, Peters EC, Hur W, et al. Synthetic small molecules that control stem cell fate. Proc Natl Acad Sci. 2003; 100: $7632-7637$.

PubMed: https://www.ncbi.nlm.nih.gov/pubmed/12794184

81. Watanabe K, Kamiya D, Nishiyama A, Katayama T, Nozaki S, et al. Directed differentiation of telencephalic precursors from embryonic stem cells. Nat Neurosci. 2005; 8: 288-296.

PubMed: https://www.ncbi.nlm.nih.gov/pubmed/15696161

82. Danjo $T$, Eiraku $M$, Muguruma $K$, Watanabe $K$, Kawada $M$, et al. Subregional Specification of Embryonic Stem Cell-Derived Ventral Telencephalic Tissues by Timed and Combinatory Treatment with Extrinsic Signals. J Neurosci. 2011; 31: 1919-1933.

PubMed: https://www.ncbi.nlm.nih.gov/pubmed/21289201
83. Maroof AM, Brown K, Shi SH, Studer L, Anderson SA. Prospective Isolation of Cortical Interneuron Precursors from Mouse Embryonic Stem Cells. J Neurosci. 2010; 30: 4667-4675.

PubMed: https://www.ncbi.nlm.nih.gov/pubmed/20357117

84. Au E, Ahmed T, Karayannis T, Biswas S, Gan L, et al. A Modular Gainof-Function Approach to Generate Cortical Interneuron Subtypes from ES Cells. Neuron. 2013; 80: 1145-1158.

PubMed: https://www.ncbi.nlm.nih.gov/pubmed/24314726

85. Tyson JA, Anderson SA. GABAergic interneuron transplants to study development and treat disease. Trends Neurosci. 2014; 37: 169-177. PubMed: https://www.ncbi.nlm.nih.gov/pubmed/24508416

86. Close JL, Yao Z, Levi BP, Miller JA, Bakken TE, et al. Single-Cell Profiling of an In Vitro Model of Human Interneuron Development Reveals Temporal Dynamics of Cell Type Production and Maturation. Neuron. 2017; 96: 949.

PubMed: https://www.ncbi.nlm.nih.gov/pubmed/28279351

87. Goulburn AL, Stanley EG, Elefanty AG, Anderson SA. Generating GABAergic cerebral cortical interneurons from mouse and human embryonic stem cells. Stem Cell Res. 2012; 8: 416-426.

PubMed: https://www.ncbi.nlm.nih.gov/pubmed/22280980

88. Chambers SM, Fasano CA, Papapetrou EP, Tomishima M, Sadelain M, et al. Highly efficient neural conversion of human ES and iPS cells by dual inhibition of SMAD signaling. Nat Biotechnol. 2009; 27: 275-280.

89. Li XJ, Zhang X, Johnson MA, Wang ZB, LaVaute T, et al. Coordination of sonic hedgehog and Wnt signaling determines ventral and dorsal telencephalic neuron types from human embryonic stem cells. Development. 2009; 136: 4055-4063.

PubMed: https://www.ncbi.nlm.nih.gov/pubmed/19906872

90. Kim TG, Yao R, Monnell T, Cho JH, Vasudevan A, et al. Efficient Specification of Interneurons from Human Pluripotent Stem Cells by Dorsoventral and Rostrocaudal Modulation: Human Interneuron Specification. Stem cells. 2014; 32: 1789-1804. PubMed: https://www.ncbi.nlm.nih.gov/pubmed/24648391

91. Maroof AM, Keros S, Tyson JA, Ying S-W, Ganat YM, et al. Directed Differentiation and Functional Maturation of Cortical Interneurons from Human Embryonic Stem Cells. Cell Stem Cell. 2013; 12: 559-572. PubMed: https://www.ncbi.nlm.nih.gov/pubmed/23642365

92. Nicholas CR, Chen J, Tang Y, Southwell DG, Chalmers N, et al. Functional Maturation of hPSC-Derived Forebrain Interneurons Requires an Extended Timeline and Mimics Human Neural Development. Cell Stem Cell. 2013; 12: 573-586.

PubMed: https://www.ncbi.nlm.nih.gov/pubmed/23642366

93. Cunningham M, Cho JH, Leung A, Savvidis G, Ahn S, et al. hPSC-Derived Maturing GABAergic Interneurons Ameliorate Seizures and Abnormal Behavior in Epileptic Mice. Cell Stem Cell. 2014; 15: 559-573. PubMed: https://www.ncbi.nlm.nih.gov/pubmed/25517465

94. Liu Y, Weick JP, Liu H, Krencik R, Zhang $X$, et al. Medial ganglionic eminence-like cells derived from human embryonic stem cells correct learning and memory deficits. Nat Biotechnol. 2013; 31: 440-447. PubMed: https://www.ncbi.nlm.nih.gov/pubmed/23604284

95. Conti L, Pollard SM, Gorba T, Reitano E, Toselli M, et al. Nicheindependent symmetrical self-renewal of a mammalian tissue stem cell. PLoS Biol. 2005; 3: e283.

PubMed: https://www.ncbi.nlm.nih.gov/pubmed/16086633

96. Pollard S, Conti L, Smith A. Exploitation of adherent neural stem cells in basic and applied neurobiology. Regen Med. 2006; 1: 111-118. PubMed: https://www.ncbi.nlm.nih.gov/pubmed/17465825

97. Pollard SM, Conti L. Investigating radial glia in vitro. Prog Neurobiol. 2007; 83: 53-67.

PubMed: https://www.ncbi.nlm.nih.gov/pubmed/17449166 
98. Onorati M, Binetti M, Conti L, Camnasio S, Calabrese G, et al Preservation of positional identity in fetus-derived neural stem (NS) cells from different mouse central nervous system compartments. Cell Mol Life Sci. 2011; 68: 1769-1783.

PubMed: https://www.ncbi.nlm.nih.gov/pubmed/20981563

99. Goffredo D, Conti L, Di Febo F, Biella G, Tosoni A, et al. Setting the conditions for efficient, robust and reproducible generation of functionally active neurons from adult subventricular zone-derived neural stem cells. Cell Death Differ. 2008; 15: 1847-1856.

PubMed: https://www.ncbi.nlm.nih.gov/pubmed/19011641

100. SpiliotopoulosD,GoffredoD,ContiL,DiFeboF,BiellaG,etal.Anoptimized experimental strategy for efficient conversion of embryonic stem (ES)derived mouse neural stem (NS) cells into a nearly homogeneous mature neuronal population. Neurobiol Dis. 2009; 34: 320-331. PubMed: https://www.ncbi.nlm.nih.gov/pubmed/19236914

101. Sun Y, Pollard S, Conti L, Toselli M, Biella G, et al. Long-term tripotent differentiation capacity of human neural stem (NS) cells in adherent culture. Mol Cell Neurosci. 2008; 38: 245-258.

PubMed: https://www.ncbi.nlm.nih.gov/pubmed/18450476

102. Koch P, Opitz T, Steinbeck JA, Ladewig J, Brüstle O. A rosette-type self-renewing human ES cell-derived neural stem cell with potential for in vitro instruction and synaptic integration. Proc Natl Acad Sci USA. 2009; 106: 3225-3230.

PubMed: https://www.ncbi.nlm.nih.gov/pubmed/19218428

103. Falk A, Koch P, Kesavan J, Takashima Y, Ladewig J, et al. Capture of neuroepithelial-like stem cells from pluripotent stem cells provides a versatile system for in vitro production of human neurons. PloS One. 2012; 7: e29597.

PubMed: https://www.ncbi.nlm.nih.gov/pubmed/22272239

104. Colasante G, Lignani G, Rubio A, Medrihan L, Yekhlef L, et al. Rapid Conversion of Fibroblasts into Functional Forebrain GABAergic Interneurons by Direct Genetic Reprogramming. Cell Stem Cell. 2015; 17: 719-734.

PubMed: https://www.ncbi.nlm.nih.gov/pubmed/26526726

105. Sun $A X$, Yuan Q, Tan $S$, Xiao $Y$, Wang $D$, et al. Direct Induction and Functional Maturation of Forebrain GABAergic Neurons from Human Pluripotent Stem Cells. Cell Rep. 2016; 16: 1942-1953.

PubMed: https://www.ncbi.nlm.nih.gov/pubmed/27498872

106. Shetty AK, Upadhya D. GABA-ergic cell therapy for epilepsy: Advances, limitations and challenges. Neurosci Biobehav Rev. 2016; 62: 35-47. PubMed: https://www.ncbi.nlm.nih.gov/pubmed/26748379

107. Upadhya D, Hattiangady B, Shetty GA, Zanirati G, Kodali M, et al. Neural Stem Cell or Human Induced Pluripotent Stem Cell-Derived GABAergic Progenitor Cell Grafting in an Animal Model of Chronic Temporal Lobe Epilepsy: Stem Cell Grafting in Chronic Epilepsy Rat Model. Curr Protoc Stem Cell Biol. 2016; 2D.7.1-2D.7.47.

PubMed: https://www.ncbi.nlm.nih.gov/pubmed/27532817

108. Lee H, Yun S, Kim IS, Lee IS, Shin JE, et al. Human Fetal Brain-Derived Neural Stem/Progenitor Cells Grafted into the Adult Epileptic Brain Restrain Seizures in Rat Models of Temporal Lobe Epilepsy. PLoS One. 2014; 9: e104092.

PubMed: https://www.ncbi.nlm.nih.gov/pubmed/25105891

109. Shetty AK. Hippocampal injury-induced cognitive and mood dysfunction, altered neurogenesis, and epilepsy: Can early neural stem cell grafting intervention provide protection? Epilepsy Behav. 2014; 38: 117-124

PubMed: https://www.ncbi.nlm.nih.gov/pubmed/24433836

110. Baraban SC, Southwell DG, Estrada RC, Jones DL, Sebe JY, et al. Reduction of seizures by transplantation of cortical GABAergic interneuron precursors into Kv1.1 mutant mice. Proc Natl Acad Sci. 2009; 106: 15472-15477.

PubMed: https://www.ncbi.nlm.nih.gov/pubmed/19706400

111. Anderson SA, Baraban SC. Cell Therapy Using GABAergic Neural Progenitors. Jaspers Basic Mech Epilepsies. 2012.

PubMed: https://www.ncbi.nlm.nih.gov/pubmed/22787598

112. Upadhya D, Hattiangady B, Castro OW, Shuai B, Kodali M, et al Human induced pluripotent stem cell-derived MGE cell grafting after status epilepticus attenuates chronic epilepsy and comorbidities via synaptic integration. Proc Natl Acad Sci. 2019; 116: 287-296. PubMed: https://www.ncbi.nlm.nih.gov/pubmed/30559206

113.Zhu Q, Naegele JR, Chung S. Cortical GABAergic Interneuron/ Progenitor Transplantation as a Novel Therapy for Intractable Epilepsy. Front Cell Neurosci. 2018; 12: 167.

PubMed: https://www.ncbi.nlm.nih.gov/pubmed/29997478

114. Sebe JY, Baraban SC. The promise of an interneuron-based cell therapy for epilepsy. Dev Neurobiol. 2011; 71: 107-117.

PubMed: https://www.ncbi.nlm.nih.gov/pmc/articles/PMC3059084/

115. Hunt RF, Girskis KM, Rubenstein JL, Alvarez-Buylla A, Baraban SC GABA progenitors grafted into the adult epileptic brain control seizures and abnormal behavior. Nat Neurosci. 2013; 16: 692-697.

116. Shibley H, Smith BN. Pilocarpine-induced status epilepticus results in mossy fiber sprouting and spontaneous seizures in C57BL/ 6 and CD-1 mice. Epilepsy Res. 2002; 49: 109-120.

PubMed: https://www.ncbi.nlm.nih.gov/pubmed/12049799

117. Hattiangady B, Rao MS, Shetty AK. Grafting of striatal precursor cells into hippocampus shortly after status epilepticus restrains chronic temporal lobe epilepsy. Exp Neurol. 2008; 212: 468-481. PubMed: https://www.ncbi.nlm.nih.gov/pubmed/18579133

118. Casalia ML, Howard MA, Baraban SC. Persistent seizure control in epileptic mice transplanted with gamma-aminobutyric acid progenitors. Ann Neurol. 2017; 82: 530-542.

PubMed: https://www.ncbi.nlm.nih.gov/pubmed/28833459

119. Romariz SAA, Paiva DS, Galindo LT, Barnabé GF, Guedes VA, et al. Medial Ganglionic Eminence Cells Freshly Obtained or Expanded as Neurospheres Show Distinct Cellular and Molecular Properties in Reducing Epileptic Seizures. CNS Neurosci. Ther. 2016; 23: 127-134. PubMed: https://www.ncbi.nlm.nih.gov/pubmed/27770487

120. Calcagnotto ME, Ruiz LP, Blanco MM, Santos-Junior JG, Valente MF, et al. Effect of neuronal precursor cells derived from medial ganglionic eminence in an acute epileptic seizure model: Effect of Neuronal Precursor Cells. Epilepsia. 2010; 51: 71-75.

PubMed: https://www.ncbi.nlm.nih.gov/pubmed/20618405

121. Paiva D de S, Romariz SAA, Valente MF, Moraes LB, Covolan L, et al. Transplantation of inhibitory precursor cells from medial ganglionic eminence produces distinct responses in two different models of acute seizure induction. Epilepsy Behav. 2017; 70: 125-130. PubMed: https://www.ncbi.nlm.nih.gov/pubmed/28427019 